\title{
Factors Affecting Fishers' Income In Sibolga City
}

\author{
Anita Harahap \\ Faculty of Economics, \\ Universitas Negeri Medan, Indonesia \\ Eko Wahyu Nugrahadi \\ Faculty of Economics, \\ Universitas Negeri Medan, Indonesia \\ Saidun Hutasuhut \\ Faculty of Economics, \\ Universitas Negeri Medan, Indonesia
}

\begin{abstract}
This study aims to investigate: (1) the effect of asset ownership on the income of fishers in Sibolga City, (2) the effect of the level of education on the income of fishers in Sibolga City, (3) the effect of working hours on fishing income in Sibolga City, (4) the effect of work experience on the income of fishers in Sibolga City. The population in this study were outboard motor fishers < 5GT with traditional fishing gear in the form of nets in Sibolga City. The sampling technique is purposive sampling with a sample size of 90 fishers. Data was collected through an open-ended questionnaire. The results of the study found that: 1) asset ownership partially had a significant effect on the income of fishers in Sibolga City. 2) the level of education partially has a significant effect on the income of fishers in Sibolga City. 3) Working hours partially have a significant effect on the income of fishers in Sibolga City. 4) Partial work experience has a significant effect on the income of fishers in Sibolga City. 5) asset ownership, education level, working hours at sea, and work experience simultaneously have a significant effect on the income of the fishers in Sibolga City.
\end{abstract}

Keywords: Asset Ownership, Education Level, Sea Working Hours, Work Experience

\section{INTRODUCTION}

Geographically, The Republic of Indonesia is located around the equator, precisely between 94 ${ }^{\circ} 45^{\prime} \mathrm{BT}-141^{\circ} 01^{\prime} \mathrm{BT}$ and $06^{\circ} 08^{\prime} \mathrm{LU}-11^{\circ} 05^{\prime} \mathrm{LS}$. Three-quarters of Indonesia's territory is a waters region, which consists of approximately 3,351 million $\mathrm{km}^{2}$ of marine area (inland waters, islands, and territorial seas) and approximately 2,936 million $\mathrm{km}^{2}$ of territorial waters of the Exclusive Economic Zone (EEZ) and continental runways. The Republic of Indonesia has the second longest coastline after Canada, which is 99,093 km (BPS, 2017b).

As the largest archipelagic country with an area of about three-quarters of the total area, Indonesian waters have 27.2 percent of all flora and fauna species found in the world, including 12 percent of mammals; 23.8 percent amphibians; 31.8 percent of reptiles; 44.7 percent of fish; 40 percent of mollusks; and 8.6 percent seaweed. Potential fish resources include large pelagic, small pelagic, other penaeid and crustacean shrimp, demersal, mollusks and sea cucumbers, squid, reef fish, ornamental fish, sea turtles, marine mammals, and seaweed. Indonesia is the country that has the second highest capture fisheries production in the world in marine waters and has the seventh highest capture fisheries production in the world in public waters (FAO, 2015). Based on data from the 2013 National Economic and 
Social Survey, it is known that only 2.2 percent of households in Indonesia who have a household head are fishers. The number is around 1.4 million head of fisher households. The average number of household members in Indonesia is around four people. It means there are around 5.6 million Indonesian people whose lives depend on the head of the household who works as a fisher. For the average income of fishers from catches at sea, around $\mathrm{Rp} 28.08$ million / year (BPS, 2017a).

Geographically, fishers are in all parts of Indonesia. This condition is not surprising considering that two-thirds of Indonesia's territory is oceanic and has tremendous fisheries potential. The highest number of fishers in Indonesia is in East Java Province (reaching more than 334,000 fishers), followed by Central Java (more than 203,000 fishers), and West Java (around 183,000 fishers), South Sulawesi, North Sumatra, and Aceh respectively becoming provinces with the 4th, 5th, 6th most significant number of fishers in Indonesia. The smallest number of fishers is found in the Special Province of Yogyakarta and North Maluku. Although North Sumatra has the fifth most significant number of fishers in Indonesia but based on data obtained from Sea and Coastal Resources Statistics, it can be seen that each province on Sumatra Island has a different contribution of fisheries to Gross Regional Domestic Product (GRDP) each year (BPS, 2017a).

Figure 1. Percentage of Contribution of Fisheries to Gross Regional Domestic Products at Current Prices by Province, 2012-2016

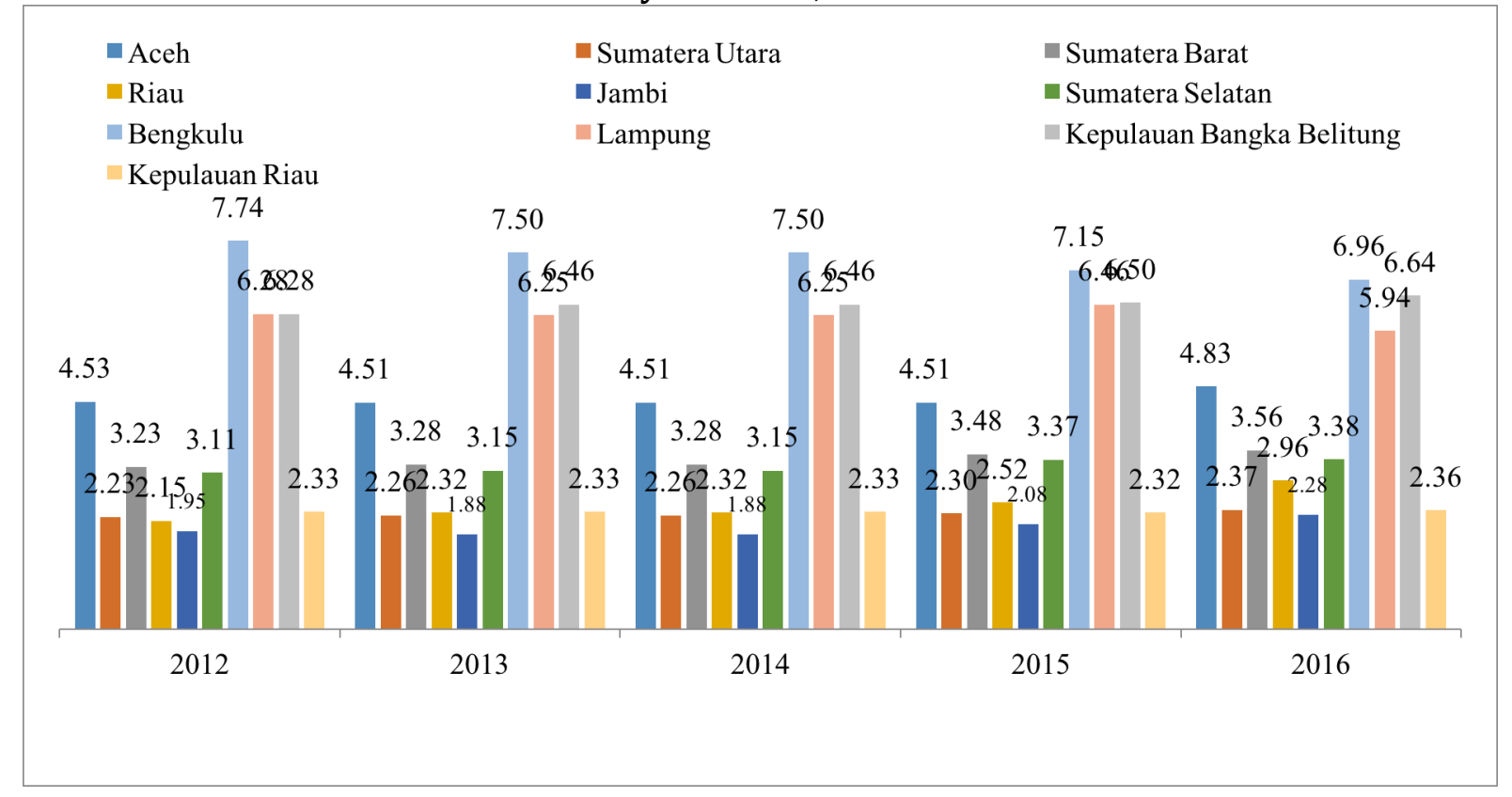

Based on figure 1, Bengkulu Province has an average percentage of fisheries contribution to the highest GRDP of 7.37 percent, then Bangka Belitung Islands has an average percentage of fisheries contribution to GRDP of 6.46 percent, Lampung has an average percentage contribution of fisheries to GRDP of 6.23 percent, Aceh has an average percentage of fisheries contribution to GRDP of 4.57 percent, West Sumatra has an average percentage contribution of fisheries to GRDP of 3.36 percent, South Sumatra has an average percentage contribution of fisheries to GRDP of 3.23 percent, Riau has an average percentage of fisheries contribution to GRDP of 2.45 percent, North Sumatra with an average percentage of fisheries contribution to GRDP of 2.28 percent, Riau Islands has an average percentage of fisheries contribution to GRDP of 2.33 percent and Jambi has an average percentage of fisheries contribution to the region $\mathrm{p}$ GRDP of 2.01 percent. 
Figure 2. Percentage Distribution of GRDP at Current Prices According to Business Fields in Sibolga City (percent), 2012-2016

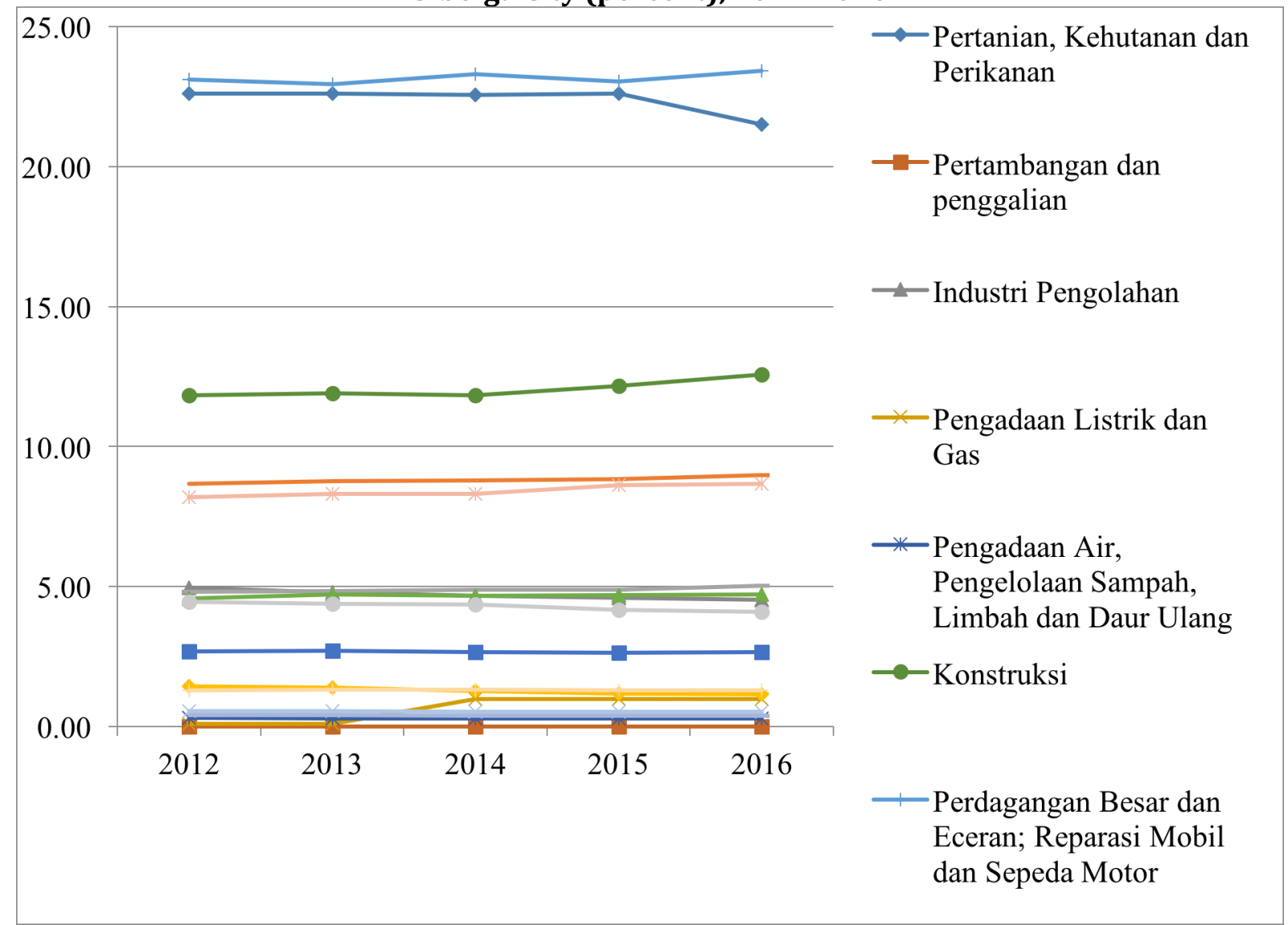

The percentage distribution of the agricultural sector to the GDP at current prices according to the business field in Sibolga City fluctuates every year. The agricultural sector became the second largest sector after the car and motorcycle repair sector. It can be seen in figure 2 that in 2012 and 2013 the distribution of the percentage of the agricultural sector to GDP was 22.59 percent and in 2014 it decreased by 22.55 percent, in 2015 it increased by 22.59 percent, and in 2016 amounted to 21.51 percent (BPS, 2017a).

Fisheries production tends to decrease every year, followed by an increase in the number of fishers in Sibolga City. Based on data from the Central Bureau of Statistics of Sibolga City, the number of fishers in 2012 increased by 0.38 percent from the previous number of 8,555 fishers in 2011 to 8,588 fishers in 2012. In 2013 and 2014 the number of fishers experienced a return of 0.51 percent and 10.26 percent from the previous number to be 8,632 and 9,518 fishers, but in 2015 there was a decrease in the number of fishers by 17.11 percent from the previous number to 7,889 fishers, and in 2016 there was an increase in the number of fishers by 6.54 percent from the previous number to 8,405 fishers.

Based on the researchers' initial observation of fishers in Sibolga City, fishers' income is largely determined by the number of fish caught. The more fish produced at sea, the income will increase, and vice versa. During the peak season, the average income of fishers is $\mathrm{Rp} \mathrm{2,000,000}$ / trip, and during the regular season, the average income of fishers is Rp 500,000 / trip. The income received by fishers in Sibolga City is still below Sibolga City Minimum Wage, which is Rp. 2,357,247. This situation shows that the income generated by fishers is certainly far from enough. This situation indicates that the income received by fishers workers is not appropriate, considering that fishers as the spearhead of the development and development of the fishing industry cannot meet their daily needs.. 
Working capital is very closely related to ownership of assets owned by fishers. Asset ownership can be reflected as ownership of factors of production and wealth by a household which can ultimately affect the level of income and household consumption. The level of education is also one of the factors that can affect the income of fishers. The new view of the Neo-Classical theory after Beyond the Solow model says that the importance of transformation in the development process is good and is not only limited to increasing allocation efficiency and factor accumulation (Capital, Labor, and Human). In this case, it has been seen that education and skills are important because education is not only able to increase the $\mathrm{H}$ factor, but also able to increase the insight into the $\mathrm{H}$ factor to accept change and increase economic growth.

Work experience is the process of forming knowledge and skills about the method of a job for employees because of this involvement in carrying out their work (Manullang, 2005). Work experience is the most influential factor in creating business growth. With the high experience, they will lead to high business growth and increase productivity. Experience is a function of income or profit.

Based on the background and formulation of the problem above, the purpose of this study is:

1. To investigate the effect of asset ownership in increasing the income of fishers in Sibolga City

2. To investigate the effect of the level of education in increasing the income of fishers in Sibolga City

3. To investigate the effect of working hours at sea in increasing the income of fishers in Sibolga City

4. To investigate the effect of work experience in increasing the income of fishers in Sibolga City

\section{LITERATURE REVIEW}

Income is determined by the ability of production factors to produce goods and services. The higher the ability of production factors to produce goods and services, the higher the income created (Sukirno, 2004). Income is the number of goods and services that meet the level of life of the community, where the existence of income owned by the community can meet the needs, and the average income owned by each soul is also called per capita income and becomes a benchmark for economic progress or development. Income (income) is the total acceptance of a person or a household in a certain period. There are three sources of household income, namely:

1. Income from salaries and wages which are remuneration from the willingness of workers. The amount of a person's salary depends theoretically on his productivity. Some of the factors that affect productivity are skills, the technical ability that a person has to be able to handle the work entrusted. The higher the position of a person, the higher the skills needed, the higher the salary or wages

2. Income from productive assets is an asset that provides revenue or service for the use of it. There are two groups of the first productive assets, financial assets such as deposits that generate interest income, shares that generate dividends and profits on capital (capital gains) when traded. Second, non-financial assets such as houses provide rental income

3. Government revenue or transfer payment is income received not as a response to input services provided but transfers provided by the government 
According to Sukirno (2006), income is the amount received by residents for their work performance for a certain period, both daily, weekly, monthly, or yearly. Moreover, there are several income classifications, namely:

a) Personal income, that is, all types of income obtained without giving any activity received by the population of a country.

b) Disposable income, that is personal income minus taxes that must be paid by the recipients of income, the remaining income that is ready to spend is called disposable income

c) National income, that is the value of all finished goods and services produced by a country in one year.

According to Kusnadi (2003), hree factors influence the increase of fisheries business income: firstly technology, which is the equipment used by fishers in fishing (production) is lighting equipment (lights) and nets. The second factor is Social Economy, includes; (a) Age. A person who is 15 years old and above can be called a fisher, under the age even though he is fishing is not referred to as a fisher. (b) Experience. If someone is considered a fisher who is 15-30 years old, over 30 years is considered an experienced fisher (c) Season. The season is very influential on the condition of fishers life, namely the west and east seasons. When the western season/famine arrives, the weather conditions are adverse, large waves occur due to strong winds, forcing fishers not to go to sea. This condition causes a decrease in the outpouring of working hours of fishing communities in fishing activities, which has an impact on decreasing the income of fishers households. Whereas during the east season it is identical to the peak season of catching or the fishers's catch is more maximal. While the third factor (3) Commerce. Fish is a commodity that is easily damaged and rotten, so the delivery from producers (fishers) to consumers must be fast so that the quality or condition is not damaged or rotten if the fish is processed. The condition or condition of this fish is very influential on the price of fish as well as nutrition.

According to Nasution (2014), production is the process of using the input to produce output. In general, the production function can be written as follows:

$$
\text { Output }=F(\text { Input })
$$

the relationship between the use of inputs in the context of creating output in the interpretation of functions is presented as follows:

$$
Q=F\left(X_{1}, X_{2}, X_{3} \ldots \ldots X_{n}\right)
$$

explanation :

Q : Output and $X_{1}, X_{2}, X_{3} \ldots \ldots . X_{n}$ Various types of inputs are used.

Output relates to products that will be produced with various criteria, and inputs include the use of labor, capital goods, raw materials, technology, and various other inputs with various units.

The production function with one input explains the relationship between the number of outputs with one input, for example, the input is labor, and other inputs are considered constant, then the relationship between the two variables is:

$$
\mathrm{Q}=\mathrm{f}(\mathrm{L})
$$

Explanation:

$\mathrm{Q}=$ output (function of $\mathrm{L}$ change); $\mathrm{L}=$ labor (variable input) 
For example, the inputs used are two, namely labor (L) and capital (K). In this case, it is assumed that the inputs $\mathrm{L}$ and $\mathrm{K}$ can change, while the other inputs remain so that the function:

$$
Q=f(L, K)
$$

Explanation:

$\mathrm{Q}=$ output; $\mathrm{L}=$ labor (input variable); $\mathrm{K}$ = Capital (input variable)

In production activities, the use of these two inputs can be exchanged, for example, L can be replaced with K, and vice versa. The concept of Cobb-Douglas production function is a function or equation involving two or more variables, where one variable is called dependent variable, which is explained $(\mathrm{Y})$ and the other is called the independent variable, which explains $(\mathrm{X})$. Usually, the resolution of the relationship between $\mathrm{Y}$ and $\mathrm{X}$ is done by regression, where the $\mathrm{Y}$ variation will be influenced by variation X. The Cobb-Douglas production function is used to determine the scale of production in the production process. General mathematical model of the Cobb-Douglas production function is as follows:

$$
Q=A L^{a} K^{\beta}
$$

Explanation:

$\mathrm{Q}=$ production output; $\mathrm{A}=$ intercept or efficiency parameter; $\mathrm{L}=$ labor input; $\mathrm{K}=$ input capital; $\mathrm{a}=$ elasticity of labor production inputs; $\beta=$ elasticity of input of capital production

The Cobb-Douglas production function can be obtained by making a linear equation as follows:

$$
L_{n} Q=L_{n} A+a L_{n} L+\beta L_{n} K+e
$$

By regressing the Cobb-Douglas production function equation, an efficiency parameter (A) and its input elasticity will be obtained. The level of efficiency is known from the return to scale value, which can be obtained by summing all the elasticities of the production factor. the requirement for the Cobb-Douglas production function is that if the sum of all the factors of production elasticity is 1 (Mankiw, 2009). The Cobb-Douglas production function, concerning $Y$ and $\mathrm{X}$, is expressed in the equation:

$$
Y=F\left(X_{1}, X_{2}, X_{3}, \ldots \ldots X_{n}\right)
$$

Explanation :

$\mathrm{Y}=$ the amount of production produced; $\mathrm{Xi}=$ The production factor used $(\mathrm{i}=1,2,3, \ldots . . \mathrm{n})$

Using the Cobb-Douglas production function, results can be seen on a scale. If the input is added twice as much, the output produced is more than twice, so that the increasing return to scale (IRTS) applies, meaning that the addition of production factors together will increase production. If output increases with a smaller proportion, then decreasing return to scale (DRTS) applies, which means that the addition together decreases production. If output increases with proportions equal to input apply constant return to scale (CRTS), ie, the addition of production factors has no impact on production (fixed production, not increase or decrease).

Human Capital is defined as the human itself, which is personally lent to companies with their capabilities, commitment, knowledge, and personal experience. Although not only seen from individuals but also as a work team that has personal relationships both inside and outside the 
company (Malhotra, 2004). Human Capital is a combination of knowledge, skills, innovation and the ability of a person to carry out their duties so that creating a value added contributed by human capital in carrying out their duties will provide a sustainable future revenue for a company (Seleim \& Bontis, 2013).

In this third and future millennium era, after economics was deemed dead by Paul Omerod, then the paradigm and direction of new economic development in the present and future is economic development that is densely populated with high-quality investment in human capital, primarily through education and training. In other words, it is necessary to develop a combination of factors $\mathrm{H}$ and factor A to manage factors L, and $\mathrm{K}$, so that quality (Q) can be produced as expected. In the new economy the factors of education, information and technology are the main drivers in economic activities in a country (Prasetyo, 2008).

Thus, human capital and technology investment reforms through better quality education in all fields in Indonesia must be carried out on a large scale in order to avoid vicious circle but, able to go to a more advanced country (good society). Development that only relies on physical resources and natural wealth can now be said to have failed. Experience shows that Indonesia's natural resources are precious but why many Indonesians remain poor and unemployed and are still "underdeveloped" almost in all fields.

The framework for promoting high and quality economic growth and having good competitiveness in Indonesia is still not supported by the role of technology and human capital (through quality education), so the impact is not the only economic quality that is not qualified, but Indonesia's economic competitiveness also remains low. The low economic competitiveness of Indonesia due to its low productivity and low productivity due to low technology and educational factors, the impact of the quality of labor also remains low and produces products that are of low quality.

Fishers are categorized as laborers who carry out their production activities by hunting fish in the sea or fishing using simple fishing equipment. The fishers do their jobs intending to obtain income for their needs. For the implementation, some equipment is needed and also influenced by many factors to support the success of the activity. In practice, the factors that affect fishers income include social and economic factors which consist of the amount of ownership of assets owned by fishers, level of education, working hours at sea/trip, and work experience. Thus the income of fishers is based on the size of the catch volume. There are still other factors that determine it, besides the social and economic factors above.

Ownership of assets is economic resources that are controlled or owned by fishing communities and have social economic benefits and can be measured in units of money in a year (units of $\mathrm{Rp}$ ). The level of education is the length of one's education, which can be seen from the level of education. Sea working hours/trips are the length of time the fishers go out to sea to look for fish catches from fishing activities when they go down the net which is calculated in units of hours in a year. Work experience is someone who has lived his profession as a fisherman for a certain period in Sibolga City which is measured in units of years.

\section{METHODOLOGY}

The scope of this study is to analyze the influence of factors such as asset ownership, education level, working hours at sea, and work experience on the income of fishers in Sibolga City. This research was conducted in Sibolga City. The reason the researchers chose Sibolga City as a place of research is that the fisheries natural resource potential possessed by Sibolga City is 
vibrant, but the ability to capture is still very small and not comparable with the existing potential..

The population is the total number consisting of objects or subjects that have specific characteristics. The population in this study were fishers with outboard motorboats with a fishing fleet of $<5$ GT in Sibolga City which amounted to 115 fishers. For a representative sample of the population, it is necessary to draw samples that are following the characteristics of the population. If the number of subjects (population) is considered too large, to save time, costs, and energy, the researcher does not examine all members of the population.

The sampling method used in this study was purposive sampling method. The purposive sampling method is sampling with specific considerations. These considerations are based on the interests or objectives of the study. The following are the criteria of fishers respondents who will be used as objects in this study are fishers with criteria that have ownership of their fixed assets, outboard motor boats used are $<5$ GT with simple fishing equipment in the form of nets. The Slovin formula determines the number of samples that will be used as respondents:

\section{Table 1. Sample Number of Fishers Outboard Motor Boats With Fleet $<5$ GT According to Districts in Sibolga City}

\begin{tabular}{|c|l|c|c|}
\hline No & \multicolumn{1}{|c|}{ Subdistrict } & Number of fishers & Sample \\
\hline 1. & North Sibolga & - & - \\
\hline 2. & Sibolga Sambas & 69 & 54 \\
\hline 3. & South Sibolga & 46 & 36 \\
\hline 4. & Downtown of Sibolga & - & - \\
\hline & TOTAL & $\mathbf{1 1 5}$ & $\mathbf{9 0}$ \\
\hline
\end{tabular}

Sumber: Data diolah, 2018

A research instrument is a tool or facility used by researchers in collecting data so that work is easy and the results are better, more accurate, complete, and systematic so that they are easier to process. The questionnaire used is a questionnaire with an open-ended question type. Openended discussion is a question that is arranged in such a way that the respondent can express his response as he wishes without any binding boundaries.

The method that will be used for the analysis of this study is multiple regression analysis using the OLS (Ordinary Least Square) method. Multiple regression analysis is a method used to determine the effect of independent variables namely asset ownership, education level, age, working hours at sea/trip and work experience with the dependent variable, namely the income of fishers. In this analysis, the approach taken is the analysis of the production function, where the production function describes the relationship between input and output. The form of the production function used is:

$$
I N C=A A S S T \beta^{1} T P^{2} J K M^{3} P K^{4}
$$

Explanation :

ASST = Asset ownership (unit Rp.); TP = Education level (unit of year); JKM = Working hours to go to sea (unit hours) PK = Work experience (units of year).

Based on the Cobb-Douglas production function, then the function is transformed into its econometric form as follows:

$$
\operatorname{LogINC}=\beta_{0}+\beta_{1} \log A S S T+\beta_{2} \log T P+\beta_{3} \log J K M+\beta_{4} \log P K+e
$$


Explanation:

INC = he capture of fisheries income in Sibolga City (Unit of Rp)

ASST = Asset ownership (unit of Rp)

$\mathrm{TP}=$ Education Level (unit of year)

$\mathrm{JKM}=$ Working hours to go to sea (hours)

$\mathrm{PK}=$ Work experience (unit of year)

$\alpha=$ constant

$\beta \_1 \beta \_2 \beta \_3 \beta \_4=$ Regression coefficient

$\mathrm{e}=$ Term of error

\section{RESULT}

Sibolga City is one of the cities in North Sumatra province. The area is $10.77 \llbracket \mathrm{km} \rrbracket \wedge 2$ or 1,077 Ha consisting of Sumatran land $889.16 \mathrm{Ha}$ of the islands land 187.84 Ha. Geographically,

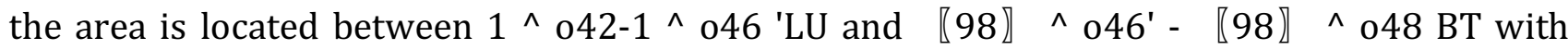
boundaries: East, South, North in Kabupaten Tapanuli Tengah, and West with Teluk Tapian Nauli. The location of the longitudinal city along the coast from North to South faces Tapian Nauli Bay. While the rivers owned, namely Aek Doras, Sihopo-hopo, Aek Muara Baiyon, and Aek Horsik and Sibolga City are located at sea level 0-5m (Badan Pusat Statistik Kota Sibolga, 2017).

Sibolga City is shaped by its location, which is located on the coast, slopes, and mountains. Located at altitudes above sea level ranging from 0-150 meters, the slope of the land varies between 0-2 percent reaching an area of 3.12 square kilometers or 29.10 percent covering the land of Sumatra covering an area of 2.17 square kilometers and islands 0 , 95 square kilometers; the 2-15 percent slope reaches an area of 0.91 square kilometers or 8.49 percent covering the land of Sumatra covering an area of 0.73 square kilometers and an area of 0.18 square kilometers; slope of 15-40 percent covering an area of 0.31 square kilometers or 2.89 percent consisting of 0.10 square kilometers of land area of Sumatra and kepuluan covering an area of 0.21 square kilometers; while the slope of more than 40 percent covers an area of 6.31 square kilometers or 59.51 percent consists of land on the mainland of Sumatra covering an area of 5.90 and islands covering an area of 0.53 square kilometers. (Pemko Kota Sibolga).

Coastal tribes as native inhabitants of the West Coast Coast of North Sumatra have livelihoods as fishers, farmers, traders, civil servants, soldiers, laborers, artisans, rickshaw pullers, and others. Following the nature of the coast, of course, most of the livelihoods of the residents are fishers. Here are some types of fishers regarding the way they catch fish:

1. Pamukek fishers are fishers who use trawls or nets to catch fish in the sea, which is driven by machinery or human power to pull nets and lift their catch fish

2. Net fishers are fishers whose work catches fish in the sea using nets driven by engines and human power together both in the sea and on the coast.

3. Pukek Tapi are fishers whose work catches trawl fish on the beach by using human labor drawn from a distance of $1 \mathrm{~km}$ from the beach together and usually the pamuge fishers will buy fish that are ready to be marketed to the community in the fishing grounds.

4. Pamuge fishers are fishers whose the job is to buy fish from fishers in the middle of the sea, and net fishers

5. Paralong-alaong/Parlanja are fishers whose the jobs is to buy fish from pamuge fishers on the beach and paralongalong/parlanja peddle fish to the community in the village.

6. Panjamu fishers are fishers whose jobs are only drying fish that have been bought from fishers fishing and then after the dried fish, they will be sold to pagudang fishers (people who buy dried fish to be marketed to other regions). 
7. Pagudang fishers are fishers whose jobs as buyers of fish that have been dried by panjamu fishers are collected in their warehousing place and sold to fish traders from outside Sibolga City.

\section{Testing of Classical Assumptions}

Normality Test

Normality test in this study using the Jarque-Bera probability value with the following results:

Figure 3. Results of Normality Test

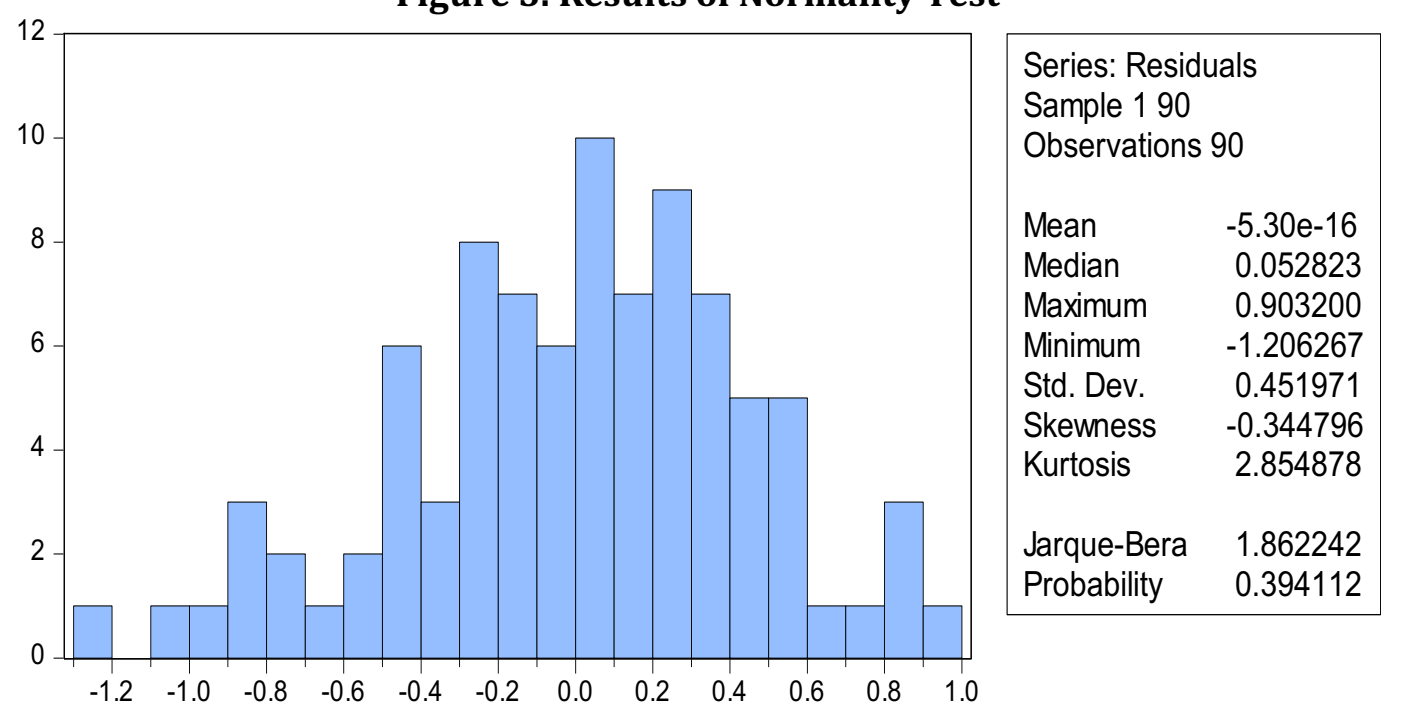

The criteria used are if the probability value is Jarque-Bera (JB) test <alpha $(0,1)$, then the data is said not to have a normal distribution and vice versa. Based on the results of the normality test table above, the probability value of Jarque-Bera (JB) is $0.394112>\alpha=0.10$, meaning that the data is normally distributed.

\section{Multicolinearity Test}

Tests on multicollinearity in this study are seen based on correlation values between independent variables. To see the independent variables protected from multicollinearity can be seen from the value of the Centered Variance Inflation Factor (VIF). Data is said to be free from multicollinearity if the Centered VIF value is $<10$ or vice versa. The following is a table of correlation values between independent variables:

Tabel 2. VIF Value from the Correlation of Independent Variables

\begin{tabular}{cccc}
\hline Variable & $\begin{array}{c}\text { Coefficient } \\
\text { Variance }\end{array}$ & $\begin{array}{c}\text { Uncentered } \\
\text { VIF }\end{array}$ & $\begin{array}{c}\text { Centered } \\
\text { VIF }\end{array}$ \\
C & 0.368580 & 155.0893 & NA \\
X1 & 0.016481 & 159.4701 & 1.127963 \\
X2 & 0.000919 & 38.71357 & 1.317095 \\
X3 & 0.001407 & 25.84578 & 1.138371 \\
X4 & 0.000107 & 22.27279 & 1.387054 \\
\hline
\end{tabular}

Source: Primary data is processed with E-Views 8.0

The Centered VIF value of the correlation of the independent variables does not exceed 10 . The Centered VIF value for the asset ownership variable (X_1) is 1.127963. Because the VIF value is $1.127963<10$, the conclusion is that the asset ownership variable does not have multicollinearity problems. Centered VIF value for education level variable (X_2) is 1.317095. Because the Centered VIF value is $1.317095<10$, the conclusion taken is that the education 
level variable does not experience multicollinearity problems. Centered VIF value for sea working hours variable (X_3) is 1.138371 . Because the Centered VIF value is $1.138371<10$, the conclusion is that working hours at sea do not experience multicollinearity problems. Centered VIF value for work experience variables (X_4) is 1.387054. Because the Centered VIF value is $1.387054<10$, the conclusion taken is that the work experience variable does not experience multicollinearity problems..

Hence, it was concluded that the correlation between independent variables, namely asset ownership variables (ASST), education level (TP), working hours at sea (JKM) and work experience (PK) did not occur multicollinearity problems.

\section{Multiple Regression Analysis}

This study uses primary data. This research is reflected in the multiple linear regression estimation models based on the results of data processing using the E-Views 8.0 program.

Tabel 3. Results of Multiple Regression Analysis

\begin{tabular}{|c|c|c|c|c|}
\hline \multicolumn{5}{|c|}{ Dependent Variable: INCOME } \\
\hline \multicolumn{5}{|c|}{ Method: Least Squares } \\
\hline Variable & Coefficient & Std. Error & t-Statistic & Prob. \\
\hline $\mathrm{C}$ & 2.795827 & 0.607108 & 4.605155 & 0.0000 \\
\hline ASSET OWNERSHIP & 0.306664 & 0.128377 & 2.388769 & 0.0191 \\
\hline LEVEL OF EDUCATION & 0.056949 & 0.030317 & 1.878421 & 0.0638 \\
\hline WORKING HOURS & 0.000665 & 0.000374 & 1.777332 & 0.0791 \\
\hline WORK EXPERIENCE & 0.038793 & 0.010341 & 3.751393 & 0.0003 \\
\hline R-squared & 0.401541 & \multicolumn{2}{|c|}{ Mean dependent var } & 6.087656 \\
\hline Adjusted R-squared & 0.373378 & \multicolumn{2}{|c|}{ S.D. dependent var } & 0.584243 \\
\hline S.E. of regression & 0.462484 & \multicolumn{2}{|c|}{ Akaike info criterion } & 1.349541 \\
\hline Sum squared resid & 18.18074 & \multicolumn{2}{|c|}{ Schwarz criterion } & 1.488420 \\
\hline Log likelihood & -55.72937 & \multicolumn{2}{|c|}{ Hannan-Quinn criter. } & 1.405545 \\
\hline F-statistic & 14.25786 & \multicolumn{2}{|c|}{ Durbin-Watson stat } & 1.488492 \\
\hline Prob(F-statistic) & 0.000000 & & & \\
\hline
\end{tabular}

Based on table 3, the income of the fishers equation model is obtained as follows :

$$
\mathrm{INC}=2,795827+0,306664 \mathrm{ASST}+0,056949 \mathrm{TP}+0,000665 \mathrm{JKM}+0,038793 \mathrm{PK}
$$

From the equation of the multiple regression model above, it can be seen that the constant value is 2.795827 . The magnitude of this constant value implies that if the asset ownership variable, education level, working hours go to sea, work experience is 0 , then the average income of traditional fishers is 2.795827 . The asset ownership regression coefficient (ASST) is 0.306664 . The magnitude of this coefficient value means that if asset ownership increases by $1 \%$, the income of fishers will increase by $0.306664 \%$.

The education level regression coefficient (TP) is 0.056949 . The magnitude of this coefficient value means that if the education level increases by $1 \%$, the income of fishers will increase by $0.056949 \%$. The working hours' regression coefficient (JKM) is 0.000665 . The magnitude of this coefficient value means that if working hours go up by $1 \%$, it will increase fishers's income by $0.000665 \%$. The work experience (PK) regression coefficient is 0.038793 . The magnitude of this coefficient value means that if work experience increases by $1 \%$, the income of fishers will increase by $0.038793 \%$. 


\section{CONCLUSIONS}

Based on the results of the study, there is a positive and significant influence between ownership of assets (X_1) on the income of fishers (Y) in Sibolga City. This condition is because if the capital issued by fishers is a little in terms of technology that supports fishing activities in the sea, the income obtained is also small. If the ownership of substantial assets of fishers to buy fishing gear is proper, then fish catches will increase, and income will also increase. Based on the results of the study, there is a positive and significant influence between the level of education (X_2) on the income of fishers (Y) in Sibolga City. The level of formal education owned by fishers in Sibolga City is still categorized as a low level of education. The number of distribution of respondents who only finished Elementary School were eight fishers or 8.9 percent, Junior High School were 49 fishers or 54.4 percent, and Senior High Schools were 33 fishers or 36.7 percent.

Based on the results of the study, there is a positive and significant influence between working hours (X_3) on the income of fishers (Y) in Sibolga City. The facts in the field show that during the full moon the fishers have 10 to 17 hours of fishing hours to catch fish in the sea while in the famine season the fishers sometimes do not go down to sea due to bad weather from October to December. Based on the results of the study, there is a positive and significant influence between the level of work experience (X_4) on the income of fishers (Y) in Sibolga City. This situation is due to the fact in the field that it appears that fishers who have more extended work experience have more ability to identify sea conditions, understand how to maintain and repair ships from damage and have a strategy to produce good fish so that it will provide an increase in fishers income.

\section{References}

BPS. (2017a). Sibolga Municipality in Figures. Jakarta. Retrieved from https://sibolgakota.bps.go.id/publication/

BPS. (2017b). Statistics of Marine and Coastal Resources. Jakarta. Retrieved from https://www.bps.go.id/publication/

FAO. (2015). Fishery and Aquaculture Statistics. Retrieved from www.fao.org/

Kusnadi. (2003). Kultur Campuran dan Faktor Lingkungan Mikro organisme yang Berperan dalam Fermentasi TeaCider. Bandung: DepartemenBiologi-FMIPA InstitutTeknologi Bandung.

Malhotra, Y. (2004). Measuring Knowledge Assets of a Nation : Knowledge Systems for Development.

Mankiw, N. G. (2009). Macroeconomics (7th ed.). New York: Worth Publishers.

Manullang, M. (2005). Manajemen Sumber Daya Manusia. Jakarta: BPFE.

Nasution, P. S. U. (2014). The Analysis of The Income of Tradisional Fisherman, Compared With Regional Wage in Meulaboh Subdistrict, Aceh Barat District, Nangroe Aceh Darussalam. Journal of Agriculture and Agribusiness Socioeconomics, 3(1).

Prasetyo, P. E. (2008). The Quality Of Growth : Peran Teknologi Dan Investasi Human Capital Sebagai Pemacu Pertumbuhan Ekonomi Berkualitas, 1, 1-15.

Seleim, A., \& Bontis, N. (2013). National Intellectual Capital and Economic Performance : Empirical Evidence from Developing Countries, 20(3), 131-140. https://doi.org/10.1002/kpm

Sukirno, S. (2004). Pengantar Teori Makro ekonomi. Jakarta: PT Raja Grafindo Persada.

Sukirno, S. (2006). Pengantar Teori Makro ekonomi. Jakarta: PT Raja Grafindo Persada. 